\title{
A Landscape Approach in Conserving Large Mammals: A Case Study from Western Terai, Nepal
}

\section{Summary}

- N M B Pradhan, Ph.D.*

1 Western Terai includes two Portected area (PA) in Nepal, which forms a part of the WWF Global 200 ecoregion, Terai-Duar Savannah and Grassland.

2 Most of the large mammals of the Western Terai are isolated, small in number and restricted to these PAs due to the degradation and fragmentation of the habitat out side the PA.

3 Existing PAs are not big enough to sustain viable population and small number of the population can be highly vulnerable to the environmental and demographic stochasticity.

4 Conservation and management of these wild animals in the large single chunk is almost impossible because of the growing number of human population around the PAs. However, conservation in such case can be done through some sort of metapopulation approaches.

5 The existing forest such as Bardia-Katarniaghat forest, Basanta-Dudhwa forest and Bardia-Sukla forest can be manage as corridors to connect these habitat patches. However, intensive restoration activity is needed in some bottleneck areas.

6 Large animals like tiger and elephant still using these areas for movement and dispersal purpose.

7 Proper management of these corridors not only provide room for the wild animals but also supply daily needs of the forest products for the local people.

8 In other to save this animal from extinction, whole Western Terai should be managed in the single landscape unit without ignoring the human component.

9 Managing these areas in a single unit may help to conserve four rhino sub population, three existing tiger population and recently isolated elephant population of the Western Terai.

10 Government of Nepal has already initiated Western Terai Landscape Project and Terai Arc Landscape project to save these wild animals from extinction. However, Government commitments only is not enough, it also seeks the regional and international support.

\section{Introduction}

The Terai-Duar Savannah and the grassland of the Western Terai landscape of Nepal form a part of the WWF Global 200 ecoregion (WWF 2000), which includes the Bardia National Park (BNP) and Suklaphanta Wildlife Reserve (SWR) within Nepal, and Dudhwa National Park (DNP) and Katarniaghat Wildlife Reserve (KWR) on the Indian side of the border. This ecoregion contains the highest densities of tiger, rhinos and the ungulates in Asia (Dinerstein 1980).

In Terai region of Nepal alone, about 133,968 ha. of forest were officially cleared for the settlement program during fifties to early eighties (HMG 1988) as well as for the eradication of malaria from the area in 1954. Migration of the people from Mid Hills to low land Terai for settlement and agricultural expansion (Shrestha 1979, Smith et al. 1998) causes major destructions and fragmentation of habitat. Human activities have modified the environment to the extent that the most common landscape patterns are now mosaic of human settlement, farmlands and scattered fragments of natural ecosystem. Such modifications have produced several undesirable changes including decline in biodiversity, fragmentation of wild animals habitat, ultimately leads to the reduction of animal numbers threatening to extinction. Most of the wild animals specially large mammals are now restricted to the few pockets of small PAs in a small number because of the ongoing fragmentation of its habitat. Small population of an organism in a small area are highly vulnerable to stochastic problem and these problem can be environmental (natural catastrophe, disease) or demographic (biased sex ratio, unstable age distribution) or genetic in nature such as loss of heritable diversity that is necessary for the fitness under existing environmental condition and adaptation to change environment in future (Foose 1993, IUCN 1998). Conservation strategy for species

044 Authors Description 2007


which are reduced in number, and which most probably will remain that way for long time, must be based on maintaining certain viable population to ensure the survival of these animals for long term.

Linking of PAs by a network of forest corridors, and their management at a landscape level as a single unit would make it possible to sustain the disappearing wildlife population through the effective dispersal and exchange of genetic materials.

The remaining forest in the Western Terai Landscape is very important for both local communities and for the big animals harbouring in the area. Besides, it also serves as corridors and connectivity between different PAs within the Western Terai. This forest area, if properly maintained at all times, may have two unique functions;

a) Provision for land connectivity between PAs, SWR and BNP as well as DNP and KWR of India.

b) Opportunities for transboundary conservation between Nepal and India.

Large mammals such as predators and the megaherbivores exert a strong influence on community structure within the diverse range of habitats occupied (Owen-smith 1988). Protecting these key stone species requires taking a representation approach designed for habitat conservation and adapting it to species conservation, so that we not only conserve individual population but also the suit of adaptations and ecological interaction associated with them (Wikramanayake et al. 1998).

\section{The causes of population extinction}

Extinction of an organism is the major outcomes of the habitat degradation, poaching, which is driven mainly by socio-economical problems such as excessive population growth, unequal wealth distribution (Vaughan 1991). As human population increase naturally demands for resources will increase, the cost for habitat preservation also increase and land base of unexploited natural habitat steadily decreased. Consequently the natural preserves become isolated remnant of the landscape surrounded by human development (Hanley 1991). Along with this, poaching of the animal and the conflict on interest between preservation and development also plays important roles in the gradual extinction of the wild animal.

\section{Habitat degradation and habitat fragmentation}

Forest landscape, a habitat for the majority of the large wild mammals around the world are undergoing major and rapid change, particularly as a result of range of human activities (Noss et al. 1994, Graetz et al. 1995 and Forman 1996). Loss and fragmentation of the habitat results in reduction population sizes, which is more vulnerable to the extinction and factor such as demographic stochasticity, loss of genetic diversity, natural calamities and diseases are believed to contribute for the extinction due to the small population (William 1993).

Small insular population may lack genetic flexibility to cope with changes in the environment, and their vulnerability worsens as undesirable traits accumulate through inbreeding. Sooner or later the result is extinction.

Fragmentation reduces biodiversity through various mechanisms such as initial exclusion of the species due to the smaller population in the smaller amount of the habitat, isolation of population, the potential increase in predation, competition, parasite, inbreeding, edge effect and disruption of natural processes. Species with small in number, large home range, limited dispersal, low reproductive potential, short life cycle, habitat interiors and exploited or persecuted by people are more likely to disappeared first due to the effects of fragmentation. (Fernandez-M. 2000). Many studies found that, the remnant habitat fragments support fewer species of habitat specialist; often, fragmented supports increased abundance of widespread generalist species. This shows that fragments of habitat are not simply the cookie-cutter pieces of the original habitat; their biota may be drastically altered (Farig 1997). Besides, fragmentation of habitat may lead to chains of indirect effects and altered ecological interactions (Harrison et al. 1999). 


\section{Poaching}

Despite of the protective measure, poaching of the wild animals continues because of exceptionally high and illegal price of the animal part in the clandestine market. Besides habitat degradation and loss of prey, large mammals like rhinoceros, tiger and elephant population severely depleted by poaching for traditional medicine (Mills and Jackson 1994). Acceleration of tiger poaching was caused by the depletion of tiger bone in 1980s stockpiles accumulated in China during the 1950s and 1960s. When the stocks ran out the traditional medicine market of tiger bone began looking for new source, shifting market pressure to areas where tiger remained relatively numerous, particularly India (Jackson and Kemf 1996) and to some extent Nepal. This fact suggest that the local level conservation only is not enough to conserve these highly prized large mammals.

The front line poachers of these animals are the local people living near by the PA (Adhikari et al. 1999). In order to decline the incentive of the poaching, the opportunity cost of the crime for these local poachers has to be increase by involving them in the conservation efforts. However, the conservation history of various countries shown that if poaching is reduced or eliminated through protection, and if water and food are available, population can recover relatively rapidly. Thus, conservation strategy not only needs to emphasised local and strict protection but also needs to focus of regional and international collaboration as well as the incentives to the deprive family living near by the PAs.

\section{Minimum Viable Population}

The long-term maintenance of genetic diversity has been considered to be a requirement for the survival of the organism, especially because the loss of this diversity has been associated with reduced fitness in local populations (Rojas 1992). The term minimum viable population is the populations sufficiently large and well distributed to survive the stochastic as well as the deterministic threats. It is the capacity of the organism to maintain itself without any significant demographic and genetic manipulation for the foreseeable ecological future maintaining a normal level of immediate fitness (individual vigor, fertility and fecundity) and has sufficient genetic variation to adapt by natural selection to changing environmental conditions (Soule 1987). Mace and Lande (1991) proposed a general scheme of guideline for population viability (Table 1).

Table 1. Mace/Lande Categories and Criteria of Threats

\begin{tabular}{|c|c|c|c|}
\hline Population trait & Critical & Endangered & Vulnerable \\
\hline Probability of extinction & $\begin{array}{l}50 \% \text { within } 5 \text { years or } 2 \\
\text { generation which ever is long } \\
\text { or } \\
\text { Any two of following criteria }\end{array}$ & $\begin{array}{l}20 \% \text { within } 20 \text { years or } 10 \\
\text { generation which ever is long } \\
\text { or } \\
\text { Any two of following criteria or any } \\
1 \text { critical criterion }\end{array}$ & $\begin{array}{l}\text { or } \\
\text { Any two of following criteria or } \\
\text { any } 1 \text { endangered criterion }\end{array}$ \\
\hline Effective population $\mathrm{N}_{\mathrm{e}}$ & $\mathrm{N}_{\mathrm{e}}<50$ & $\mathrm{~N}_{\mathrm{e}}<500$ & $\mathrm{~N}_{\mathrm{e}}<2,000$ \\
\hline Total population $\mathrm{N}$ & $\mathrm{N}<250$ & $\mathrm{~N}<2,500$ & $N<10,000$ \\
\hline Sub population & $\begin{array}{l}2 \text { with } \mathrm{N}_{\mathrm{e}}>25, \mathrm{~N}>125 \text { with } \\
\text { immigration }<1 / \text { gen. }\end{array}$ & $\begin{array}{l}5 \text { with } \mathrm{N}_{e}>100, \mathrm{~N}>500 \text { or } 2 \text { with } \\
\mathrm{N}_{e}>250, N>1,250 \text { with } \\
\text { immigration }<1 / \text { gen. }\end{array}$ & $\begin{array}{l}5 \text { with } \mathrm{N}_{e}>500, N>2,500 \text { or } \\
2 \text { with } \mathrm{N}_{e}>1000, N>5,000 \text { with } \\
\text { immigration }<1 / \text { gen. }\end{array}$ \\
\hline Population Decline & $\begin{array}{l}>20 \% / y r \text { for last } 2 \text { yrs or }>50 \% \text { in } \\
\text { last generation }\end{array}$ & $\begin{array}{l}>5 \% / y r \text { for last } 5 \text { yrs or }> \\
10 \% / g e n . \text { for last } 2 \text { generation }\end{array}$ & $>1 \% / y r$ for last 10 years \\
\hline Catastrophe: Rate and Effect & $\begin{array}{l}>50 \% \text { decline per } 5-10 \text { yrs or } \\
2-4 \text { generation; subpops. highly } \\
\text { correlated }\end{array}$ & $\begin{array}{l}>20 \% \text { decline/ } 5-10 \text { yr, } 2-4 \text { gen. }> \\
50 \% \text { decline per } 5-10 \text { yrs, } 5-10 \\
\text { gen. with subpops. correlated }\end{array}$ & $\begin{array}{l}>10 \% \text { decline/ } 5-10 \mathrm{yr}, \\
>20 \% \text { decline/ } 10-20 \mathrm{yrs} \text {, or } \\
>50 \% \text { decline } / 50 \mathrm{yrs} . \\
\text { with subpops. correlated }\end{array}$ \\
\hline \multicolumn{4}{|r|}{ 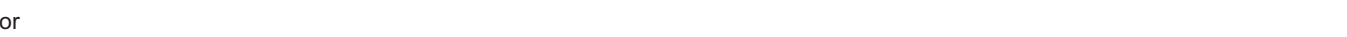 } \\
\hline Habitat change & $\begin{array}{l}\text { resulting in above population } \\
\text { effect }\end{array}$ & resulting in above population effect & $\begin{array}{l}\text { resulting in above population } \\
\text { effect }\end{array}$ \\
\hline \multicolumn{4}{|r|}{ 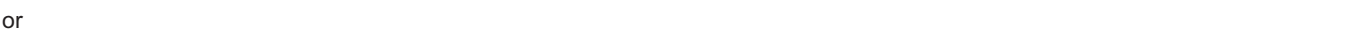 } \\
\hline $\begin{array}{l}\text { Commercial exploitation or } \\
\text { Interaction/Introduced Taxa }\end{array}$ & $\begin{array}{l}\text { resulting in above population } \\
\text { effect }\end{array}$ & resulting in above population effect & $\begin{array}{l}\text { resulting in above population } \\
\text { effect }\end{array}$ \\
\hline
\end{tabular}


According to his scheme the population should be big enough to assure viability. Population less than 10,000 is considered as vulnerable, even according to his scheme there should be at least 2 sites with 2500 in number at one subpopulation with effective population size of 250 to upgrade population from endangered to vulnerable. Thus question may arise, can we able to set aside a single chunk of habitat to ensure viable population of this animals? Even though, if it is possible the management of such set aside area is becoming increasingly difficult and sophisticated, in part because of the growing number of humans. Hence, viable population strategies will require development of Metapopulation to achieve "population that is large and widely distributed enough to have an acceptable probability of surviving the stochastic risk» (Foose 1993)

\section{Metapopulation}

Literally, it is a «populations of population» found in a patchy landscape or population which is discontinuous in distribution over spatially disjunct patches of suitable habitat «patches» separated by intervening unsuitable habitat «Matrix». Movement of animals between the suitable habitat patches is not routine, the consequent, movement between patches is somewhat restricted. However there is occasional dispersal between the patches, founding new population in empty patches. A metapopulation is thus, the process of population turnover, extinction and establishment of new population (Hanski 1991).

As in island biogeography theory, metapopulation theory also deals with patchy habitat, extinction and colonisation, but differs in assuming a network of small patches instead of persistence mainland habitat. Dispersal of animals among the habitat fragments is the major concern in the case of metapopulation. In adequate dispersal will lead not only to a local extinction but also to regional extinction of the species. Metapopulation model predicts non-linear effects of habitat loss; as habitats are destroyed in a region, species will become extinct when the amount of the remaining habitat falls below a critical threshold set by their dispersal and extinction parameter (Harison et al. 1999).

A metapopulation persistence depends on the combined dynamics of extinction within given patches and recolonization among patches by dispersal. So long as the rate of recolonization exceeds the rate of extinction, the metapopulation can persist even though no given sub population in a patch may survive continuously over time (McCullough 1996). Balance may reach when, on average, an equal number extinction and colonization events occur each year. Thus a metapopulation depends on survival of species in fragmented habitat, distinction between habitat patches in the surrounding matrix, origin, size and shape of the habitat patches as well as the role of the habitat corridors in facilitating dispersal and hence maintain viable population and the role of the human in landscape development and management (Hanski 1991).

\section{Existing situation in Western Terai}

\section{Western Terai}

Western Terai region includes the Bardia-Suklaphanta landscape complex (Bardia, Kailali and Kanchanpur district) of the Mid and Far Western region of Nepal and the part of north western part of the India.

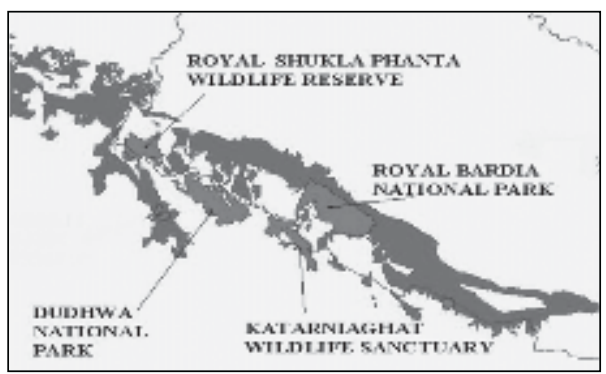

Western Terai Landscape in Nepal and India showing PAs and its connectivity

Map Source: WWF Nepal Program 
Lowland and Siwalik forest cover form a continues belt of large mammal's habitat in the Gangetic flood plain, is now increasingly fragmented as a result of the conversion of forest land into agricultural purposes. National Parks and Wildlife Conservation Act 1972, provided the legal basis for the establishment of BNP and SWR in 1970s. Although, this initiative helps to secure some habitat for the wild animals, it did not halt degradation of critical wildlife habitat outside the PAs. Increasing degradation and fragmentation of habitat outside the PA and poaching has seriously threatened the survival of many large mammals. As an isolation unit, these PAs will not be able to maintain viable population of large mammals over the next 100-200 years (Bhuju et al.2001).

\section{Forest and Forest type}

Western Terai forest has been categories in to 5 types based on land terrain and land tenure (Table 2); a) Production forest, forest area which is less than $15 \%$ of slope in plain area and 15 to $60 \%$ slope in hills area is categories as production forest. b) Protection forest: forest with more than $60 \%$ slope or rugged area. c) Potential community forest: degraded forest area or plantation area which can be handed over to local user groups d) private forest: plantation raise in the private land and e) protected area. Land area designated for conservation under the National parks and Wildlife Conservation Act 1972.

Table 2. Different types of forest area (ha) in the western Terai of Nepal based on land terrain and tenure.

\begin{tabular}{l|l|l|l|l|l}
\hline $\begin{array}{l}\text { Western Terai } \\
\text { District }\end{array}$ & $\begin{array}{l}\text { Production } \\
\text { Forest }\end{array}$ & $\begin{array}{l}\text { Protection } \\
\text { forest }\end{array}$ & $\begin{array}{l}\text { Potential } \\
\text { Community Forest }\end{array}$ & $\begin{array}{l}\text { Protected } \\
\text { Area }\end{array}$ & Total \\
\hline Bardia & 14792 & 14681 & 4273 & $129500^{*}$ & 163246 \\
Kailali & 64196 & 133128 & 12400 & - & 209724 \\
Kanchanpur & 23536 & 31165 & 2999 & 32000 & 89700 \\
Nepal Terai & 298345 & 711364 & 184214 & $397100^{*}$ & 1591023 \\
Western Terai & 102524 & 178974 & 19672 & $161500^{*}$ & 462670 \\
& $(34.36)$ & $(25.10)$ & $(10.67)$ & $(40.66)$ & $(29.08)$ \\
\hline
\end{tabular}

* Protected area including buffer zone

Source: DNPWC 2002, and Jha et al. 2001.

Bhuju et al. 2001 has classified the western Terai forest in to 3 different categories based on physiographic zone. Terai, Bhabar and Churia forest.

Terai forest: This resemblance with the production forest of the first categories. About 48 $\%$ of the forest is dominated by Sal (Shorea robusta) and Asna (Teminalia alata) a major hardwood forest tree. Where as $32 \%$ were only Sal dominated and $20 \%$ is mixed forest of hardwood with Lagerstroemia parviflora and Mallotus phillippensis.

Bhabar forest: This type also resemblance to the production forest and some protection forest of the categories first is a narrow belt forest in Bhabar zone with Shorea robusta, Teminalia alata, Mallotus phillippensis, Acacia catechu and Adina cordifolia species.

Churia Forest: This falls under the protection forest with high density of stem. Shorea robusta, Teminalia alata, Pinus roxburghii, Lagerstroemia parviflora, Anogeisus latifolia, Schleichera oleosa and Quercus lanata are the major tree species associated in this forest type.

A recent survey carried out (Bhuju et al. 2001) in the area shows that Terai and Bhabar forest has low basal area and low stem density than Churia forest. Similarly $32 \%$ of the Terai falls under degraded categories while the Bhabar and the Churia such categories were 18.6 and 11.48 percentage respectively. The high degradation of the Terai forest was mainly due to the rampant tree felling both legally as well as illegally and continued encroachment for settlement and the cultivation.

Once intact forest of the western Terai has been now fragmented into 49 patches. Jha et al. 2001, surveyed 14 forest patches in Bardia 24 in Kailali and 11 in Kanchanpur 
District of Nepal Size of this patches vary from 178 ha to more than 50000 ha. Western Terai represent the important tropical flora, 455 plant species belonging to 387 genera and 155 families were recorded so far from this region (Jha et al. 2001).

\section{Faunal diversity}

The western Terai region shelters a wide variety of large mammals, among them most important are elephant (Elephus maximus), tiger (Panthera tigris) greater one horn rhinoceros (Rhinoceros unicornis). About 57 to 68 wild elephants are estimated in this region among them 45 to 50 resides in BNP which is believed to influx from DNP India, in 1994, where as 12 to 18 in SWR and the near by Churia forest (tenVelde 1999). In the Indian side west to Suklaphanta Wildlife Reserve, about 600 to 700 elephants were estimated in Rajaji National Park where as about 300 to 400 in Corbett National Park (Jhonsing et al. 1999). Smith et al. 1998 estimated approximately 242 tigers in the Western Terai in three different populations (Table 3). The Bardia population are estimated to have a density of one tiger per $37 \mathrm{sq}$. km, where as Suklaphanta population is estimated at one tiger per $20 \mathrm{sq}$. km (Smith et al. 1998). To ensure the new viable breeding population and safeguard the source population from natural calamities, some greater one horned rhinoceros has been translocated to western Terai area from Kaziranga National Park (Goswami 1993, Sinha et al 1993,), India and Chitwan National Park, Nepal (Pradhan 2001).

At present there are altogether 110 rhinoceros harbours the area. Out of that about 20 is estimated in Dhudwa National Park India (Pradhan 2001), 80 in Bardia National Park, Nepal (S. R. Bhatta per. communication), Six in Suklaphanta Wildlife Reserve, Nepal (DNPWC 2002), and Four in Katarniaghat Wildlife Reserve, India (Pradhan 2001). Beside, this region support some 45 mammals, 253 species of birds, 20 species of herpatofauna, 57 species of fish (Jha et al. 2001). Other most important animals found in the area are highly endangered hispid hare (Caprolagus hispidus), hynea (Hyaena hyaena), Nepal's last surviving population of black buck (Antilope cervicapra) and a largest herd of swamp deer (Cervus duvauceli). Two species of crocodile, gharial (Gavialis gangeticus) and marsh mugger (Crocodilus palustrus) and the highly endangered gangetic dolphin (Platanista gangeticus) are among the important fauna of this region.

\section{Corridors, connectivity and animal movement}

Forest of Western Terai has potential for a land-based connectivity, which could link Nepal's BNP and SWR with DNP and KNP in India. Furthermore, the Churia forest which stretches from the foothill forest of Utter Prudish, India: reaches the foothills of Kanchanpur and continue on to Bardia National Park is one of the good tract of forest remaining for the movement and dispersal of large wild animals of the region (ten Velde 1999, Bhuju et al 2001). Following remnant forests has been identified as the potential corridors and which is very important from the large mammal conservation point of view (WWF 2000, Jha et al. 2001, Bhuju et al. 2001,).

\section{Bardia-Katarniaghat Corridors}

About six km long natural remnant forests south to the BNP connect this park to KWR. Although, the corridor forest is very narrow and heavily disturbed by the human activities, elephants and rhinoceros are still known to use this corridor for movement (DNPWC 2002, WWF 2001, Bhuju et al.2001 and Jha et al. 2001). Certain portion of these corridor forests has already been managed as the buffer zone forest of the BNP. However, some portion south to the buffer zone has highly degraded and not much wider due to the encroachment for the agricultural purpose and people's need for the basic forest product. Experience from management of the buffer zone has shown that proper management of this area may increase the width and the quality of the forest.

Four rhinoceros from the Bardia population has moved down to KWR using this corridor and settle there since from 6 yrs. Not much detail is know about this population, however, during rhino count 2000 it was noticed that northern part of this reserve has been used as a dispersal area of the Karnali flood plain rhinoceros of BNP. Jnawali 1995 calculated 
the average annual home range of Karnali floodplain population is $28.5 \mathrm{sq}$. Km., and the population of rhinoceros is increasing satisfactory, which ultimately need more room to sustain this animal viably.

\section{Basanta - Dudhwa Corridors}

This corridor connect forest in the Churia hills, Nepal with DNP, India though the existing Basanta forest area in Kailali District of Nepal. This is an important corridor, which connect forest patches of two different physiograpy zones. Basanta forest is still good natural block of forest with an area of $175 \mathrm{sq} \mathrm{km}$ is central to linkage between Indian and Nepalese forest and even to SWR in the west (Bhuju et la 2001). Human related impacts, primarily from immigration, timber felling, forest encroachment, man made forest fire, cattle grazing, fodder and fuel wood collection have a tremendous negative impact on this forest. The corridor forest on the Indian side near by border remains only $500 \mathrm{~m}$ wide due to the rapid emerging settlement (Jha et al. 2001). Immediate, conservation measure should be necessary to intact this area. Big animal like tiger, elephants and deer has known to use this area for the movement and as for dispersal. One male rhinoceros which was first observed in SWR in 1995 was believed to be comes from Dhudwa National Park, India via using part of this corridor.

\section{Bardia-Suklaphanta Corridors}

The east west corridor of the Western Terai extending about $125 \mathrm{~km}$ long and 4 to $12 \mathrm{~km}$ width comprises Churia hills and its foothill forest (ten velde 1999, Jha et al. 2001). This will be the major transboundary corridor to facilitate movements of elephant, rhino and tiger between forested Uttar Pradesh (India), SWR and BNP. In the past, elephants used to move from Uttar Pradesh, India (primarily from Haldwani and Takanpur forest Division) to SWR through Mahakali River and then continue onward along the Churia foothills to Bardia National Park (ten Velde 1999). The last movement of the elephant in this route was recorded in 1994. The sudden influx of elephant in Bardia National Park from three to 50 elephant was recorded in the same time (Personnel experience) and since then this elephants appear to become permanent residence of the park. This is may be due to the habitat degradation and fragmentation in Kailali and Kanchanpur border of Bardia Suklaphanta corridor. At present elephant movement is restricted to the Mahalkheti area of the Kanchapur district only (ten Velde 2001, Jha et al. 2001,).

\section{Critical habitat in Western Terai}

Jha et al. 2001 has identified 13 critical habitats in Western Terai region based on declining biodiversity, degrading habitats, increasing encroachment and settlements that required immediate attention for the biodiversity conservation at landscape level. Critical area corresponding issues and causes for attention needs is shown in Table 4.

Table 4. Critical Habitat in the Western Terai, Nepal

\begin{tabular}{l|l|l|l}
\hline Critical area & Issue & Importance spp. & Remarks \\
\hline Bhadaiya Tal & Wet land conservation & Fish and Bird & Lake degradation \\
Black buck Con. Area & Threathened spp declining & Black buck & Poorly managed \\
Patharbhauji & Forest degradation & Reverine forest & Potential corridor \\
Chuha-Dododhari-Lamki & Settlement increasing & Sal forest & Olephant Route \\
Ramashikharjhala Sadepani & Forest encroachment and settlement & Sal and Mixed forest & Old elephant Route \\
Andaiya Masuriya & Forest encroachment and settlement & River. and sal forest & Old elephant Route \\
Shripur, Chaumala & Forest encroachment and settlement & Sal ,Terminalia forest & Old elephant Route \\
South of Basanta forest & Illegal encroachment & Sal ,Terminalia forest & Potential corridor \\
Godawari-Malakheti & Settlement increasing & Sal ,Terminalia forest & Elephant route \\
Kishanpur-Jhalari & Settlement increasing & Sal, Terminalia forest & Elephant route \\
Daiji, Suda Mahendranagar & Settlement increasing & Sal forest & Elephant route \\
Brahmadev,Metana & Settlement increasing & Sal and river. forest & Elephant route \\
Settlement in SWR & Illegal settlement & Sal forest & Policy implementation \\
\hline
\end{tabular}




\section{Discussion}

Extinction is the state in which all members of a groups of organisms, such as a species, population, family or class, have disappeared from a given habitat, geographic area, or the entire world. Currently, the loss of biodiversity is occurring very rapidly, clearance of large chunk of forest for the agricultural and settlement purpose, construction of development projects and rampant poaching by ever increasing human population has caused massive degradation and fragmentation of natural habitat, resulted the declining wild animals and even extinction from the given habitat or from certain geographic region (Panwar 1987, Jhonsingh et al 1999). Once freely ranging population of greater one horn rhinoceros (IUCN 1998) was completely eliminated from the Western Terai, whereas wild elephant and tiger has been restricted to only in PAs in very small number. A dramatic collapse of animal may cause population bottleneck, which will usually initiate an interval during which population lack some or more genetic diversity of the source population (Frankel and Soule 1981). Larger population will have more genetic diversity when population size decreased this diversity will greatly affected by inbreeding, in which the harmful recessive alleles of individuals of the population start to appear in their homozygous form. These homozygous alleles have likely to spread very quickly in small population, which may causes, the diminishing of individual abilities to survival and reproduction of the whole population (Brookfield 2001). Loss of genetic diversity in individual is highly affected by the period of population bottleneck and the size of the population. The most vulnerable population are those, where population bottleneck will remain for the long period of time.

Dinerstein et al. 1990, concluded the importance of population size and period of bottleneck to maintain genetic variability of one horn rhinoceros. Maintenance of high genetic variability $(\mathrm{H} 0=.099)$ of one horned rhinoceros in Chitwan National Park Chitwan National Park is may be because population size remained large prior to 1950 (more than 1000) and population bottleneck (about 80) for only about 10 to 15 yrs. (Pradhan 2001), In case of normal tiger population, the quasi extinction probabilities model generated using fieldderived vital rate shows that even small, insular population (e.g. with six breeding tigresses) have low probabilities of extinction. This may be because of short duration of population bottleneck and capacity for population persistence due to high reproductive potential of the tigers, which is a typical pattern of large felids (Karanth and Stith 1999). This suggest that there might be some probability that, large mammals of the Western Terai may still have good genetic variability, because isolation of population started only since from recent decades and most of the large mammals have long average generation time. However, in general it has been proved that small population and long period of bottleneck ultimately leads to the population extinction. Very little work has been carried out regarding the minimum viable population (MVP) of large mammals. Belovsky (1987) estimated that the largest mammalian carnivores (10 - $100 \mathrm{kgs})$ and largest mammalian herbivores (100 - $1000 \mathrm{kgs}$ ) could be expected to persist for 100 yrs in 0 to $22 \%$ and in 4 to $100 \%$ respectively in the present land area of habitat. From the conservation point view it is very essential to know what is the minimum viable population for the animals. Mace and Lande 1991 have proposed some rule of thumb (see table 1) for the different stages of population extinct. Soule 1987 assumes a $95 \%$ expectation of persistence, without loss of fitness, for several centuries. IUCN 1998, recommended, population of 100 or population can be rapidly expanded to 100 or more in a 10 different site in other to avoid risk of having « all the eggs in one basket» for the greater one horn rhinoceros. According to above rules, all most all of the big mammals of the Western Terai are critical in situation because they are isolated and very low in number, in which there long term persistence is by no means guaranteed. However, various species, e.g. rhino in Nepal (Dinerstein 1991), golden hamster, and northern hemisphere seal (Soule 1987) tiger (Smith, et al. 1998) has got through the population bottleneck without loosing any genetic variation. The real danger is random demographic or environmental events and diseases that can easily wipe out a population regardless of the population size (Shaffer 1981). Thus the best solution is to increase land base by connecting different patches through corridors and manage population in a metapopulation approach.

Smith et al. (1998) described four sub population of tiger (three in Western Terai) and one remnant population, which is believe to isolated from a large single contiguous 
population formally extending from Corbett National Park, eastward across Nepal to Bhutan and Assam. Former same population of elaphant in wesern terai has now divided into two population since from some 8 years. However, occasional records of the tiger, elephants in the Bardia Suklaphanta corridor and Basanta Dhudwa corridor, and regular movement of translocated rhinoceros within these corridors has indicated that there is great potential for the conservation of large mammals in metapopulation approach. Distributing animals over multiple subpopulations and linking these area by some short of connectivity will actually increase the effective size of the total number maintained in term of the capacity to tolerate the stochastic problem (Rojas 1992). Thus, it has been assumed that ecosystems conservation in the landscape approach not only support the viable single population but also help to maintain it in more system viability approach. Fortunately, the situation of Western Terai is not that much worse, existing ruminant forest out side of PAsPAs which still connect various protected area excepts some bottleneck (critical areas), can be manage either as corridors or as the habitat patch depends upon the spatial distribution of the forest in the area. If timely attention has not been given right now the existing isolated population of Western Terai can extinct in various causes such as no positive equilibrium as well as immigration equilibrium stochasticity of the last remaining population of large mammals.

The forest area of low land (bellow $15 \%$ slope) is very much important for the linkage of the different patches of the wildlife habitat may contradict with timber production objective. Ecological integrity of the area should be maintained without ignoring the human community. Experience from the past has shown that imposing the strict rules for the conservation may adversely affect social impact on the local people. Loss of traditional right to use natural resources and damage caused by the increasing wild animals imposed a heavy indirect cost due to time and money investment of the local people (Studsrød and Wegge 1995). Participatory conservation approach in the buffer zone of Chitwan National Park and Bardia National Park has shown that an area can be managed for the production and protection purposes. Bagmara Community Forest in the buffer zone of Chitwan National Park is the good example of participatory conservation. Increasing wild animal population in the community forest has tremendously attracted tourism in the area while the regular maintenance of the resource provides daily need of timber fuel wood and fodder resource for the local people. The program with community mobilization principle, enhance to build guardianship in the conservation, hence develop strong social capital towards conservation. There should be a strong linkage between conservation and development. Annapurna conservation Area and Buffer Zone program in the Nepal's PAs has demonstrated the possibilities of linking conservation and development (Nepal 1993).

Initiation of Western Terai Tiger Rhino Elephant Complex program, transboundary dialogue between Nepalese and Indian authority and translocation of more than 70 rhinoceros are the indication of Nepalese Government commitment in the conservation of Western Terai in the single landscape unit. However, only commitment of Government is not enough for the successful conservation, it also requires financial input from the international community also.

\section{Conclusion}

PAs of the Western Terai still supports some potential large mammal which can be build in to a viable population. Massive destruction of habitat in the past and ever increasing human population and poaching puts this animal in to great danger. Small population in small area are highly vulnerable to the extinction because of demographic and environmental stochasticity. There is great need to build these animals into some viable population. Like in most of the cases, the PAs of the Western Terai also suffer from the growing population pressure and most of the habitat out side the PAs is not able to sustain minimum viable population of this large mammals. Thus, to safeguard these animals from environmental and demographic stochasticity and to maintain genetic diversity this population has to manage in the metapopulation approach. Existing forest in the western Terai still can serve as the corridors for dispersal of these animals in to different PAs. Proper management of these forests not only serve as corridor, but also can provide more room for the dispersal of animals. 
Assuring increase of population only may not enough to safeguard this animal for long term. Externalities like poaching and the hostile nature of the human population may conflict with the conservation goal. Holistic approach of conservation not only provides refuge area for the wild animals, it also provide daily need of forest resource of the local people. Building social capital of the local people towards it is very much essential for the successful conservation.

Some initiation has been already started to conserve large mammals in the western terai as a landscape unit. Successful rhino translocation activities, satisfactory increment of the source and sink population and encouraging support from the local people shown that there is great potential and hope to conserve this animals in metapopulation approach. However, Government efforts only is not enough to conserve this animals, the long term success will be determine by further supports from local people and regional and international cooperation and collaboration.

\section{References}

Adhikari, T. R., N. M. B. Pradhan \& N. Poudle (1999) A strategy to combat poaching in Chitwan Valley. Department of National Parks and Wildlife Conservation, Nepal. Unpbl.

Belovsky, G. E. (1987) Extinction models and mammalian persistence. In Viable population for conservation. (ed. M. E. Soule), Cambridge University Press, Cambridge.

Bhuju, D. R., A. Rijal \& P. B. Yonzon (2001) Strategic planning to maintain the ecology of the Western Terai - Churia forest, Nepal. A draft study report submitted to The World Wildlife Fund Nepal Program. Resources Himalayas, Kathmandu, Nepal.

Brookfield, J. F. Y. (2001) Population bottlenecks, Current Biology, 11, 24, R1000 de Silva, M., Jayaratne, B.V.R. \& P. K. de Silva (1995) The status and other ecological aspects of the elephant population in Ruhuna National Park, Sri Lanka. J. South Asian Natural History, 1,2, 185 \pm 202.

Dinerstein, E. (1980) An ecological survey of the Royal Karnali-Bardia Wildlife Reserve, Nepal. Part III: ungulate populations. Biological. Conservation, 18: 5-38.

Dinerstein, E. \& G. F. Mccracken (1991) Endangered greater one horned rhinoceros carry high levels of genetic variation. Conservation Biology, 4, 4, 417 - 422

DNPWC (2002). Annual report, Department of National Parks and Wildlife Conservation, Nepal

Fahrig, L. (1997) Relative effects of habitat loss and fragmentation on population extinction. Journal of wildlife Management, 61.3.

Fernandez-M, J. (2000) Habitat fragnetation http://www.umsl.edu/ sorkv/Bio240/Pages/Fragmentation.html

Foose, T.J. (1993) Global management of rhinos. Rhinoceros Biology and Conservation (ed.O. A. Ryder), pp. 32-47. Proceeding of an International Conference, Zool Society, San Diego, USA.

Forman, R.T. (1996) Land mosaics the ecology of landscapes and regions. Cambridge University Press, New York.

Frankel, O. H. \& M. E. Soule (1981) Conservation and evolution. Cambridge University Press. Cambridge.

Goswami, U. C. (1993) Analysis of certain strategies of conservation and propagation of Rhinoceros unicornis. Tiger paper, XX, 4, Oct - Dec., 16-22.

Graetz, R.D., M. A. Wilson \& S.K. Campbell (1995) Land cover disturbance over the Australian continent: a contempary assessment. Biodiversity Series, Paper No. 7 Department of the Environment Sports and Territories, Canberra.

Hanley, T. A. (1991) Old growth forests and biological conservation in temparate forests of North America. Wildlife Conservation, Present trends and Perspectives for the 21st century (ed. Naoki Maruyama et al.) pp. 69-73. Proceeding of thelnternational symposium on Wildlife Conservation in Tsukuba and Yokohama, Japan

Hanski, I. (1991) Metapopulation dynamics: brief history and conceptual domain. In Metapopulation Dynamics: Emphirical and Theoritical Investigation.(eds. M. Gilpin and I. Hanski) pp, 3-16, Biological Journal of the Linnean Siciety, 42

Harrison, S. \& B. Enilio (1999) Habitat fragmentation and large scale conservation: what do we know for sure. Ecography, 22, 225-232 
HMG (1988) Master Plan for the Forestry sector of Nepal: Main Report. Ministry of Forest and Soil Conservation, Kathmandu Nepal.

IUCN (1998) Asian rhinos the Action Plan for the conservation. Asian Rhino Specialist Group, IUCN, web site: http://www.rhinos-irf.org/specialists/AsRSG/AsRSG.html

Jackson, P \& E. Kemf (1996) Wanted alive! Tiger in the wild. WWF status report. Gland, Switzerland.

Janawali, S. R. (1995) Population ecology of greater one horned rhinoceros (Rhinoceros unicornis) with particular emphasis on habitat preference, food ecology and ranging behavior of a reintroduced population in Bardia National Park in low land Nepal. Doctor Seientiarum Thesis. Department of Biology and Nature Conservation, AUN, Norway.

Jha, P. K., S. Parajuli, S. N. Jha \& P. Lamsal (2001) Nepal landscape Biodiversity Project: Bardia Shuklaphanta landscape complex. A draft report submitted to Nepal Biodiversity Landscape Project, HMG/MFSC/UNDP/GEF/SNV.

Johnsingh, A. J. T. \& C. Williams (1999) Elephants corridors in India: Lesson for other elephant range countries. Oryx, 33,3, 210 - 214.

Karanth, U. K. \& B. M. Stith (1999) Prey deplitionas a critical determinant of tiger population viability. In Riding the Tiger: Tiger conservation in human-dominated landscape. (eds. J. Scidensticker, S Christie \& P. Jacson), The zoological Society of London and Cambridge University.

Mace G. M. \& R. Lande (1991) Assessing Extinction Threats: Toward a Reevaluation of IUCN Threatened Species Categories. Conservation Biology 5 (2), 148-157.

McCullough, D. R. (1996) Introduction. In Metapopulation and wildlife conservation.(ed. D. R. McCullough). Island Press, Washington DC.

Mills, J.A. \& P. Jackson (1994) Killed for a cure: A review of the world-wide trade in tiger bone, Cambridge, Traffic International.

Nepal, S.K. \& K.E. Weber (1993) Struggle for existence: Park-people conflict in Royal

Chitwan National Park, Nepal. Asian Institute of Technology, Bangkok, Thailand.

Noss, R.F., A. Y. Cooperrider (1994). Saving nature's legacy protecting and restoring biodiversity. Island Press, Covelo, California.

Owen-smith R. N. (1988) Megaherbivores, the influence of very large body size on ecology. Cambridge University Press Cambridge.

Panwar, H. S. (1987) Project Tiger: The reserve, the tigers and their future. In tiger of the World: The biology, Biopolitics, Management and Conservation of an endangered species (ed. R. L. Tilson and U. S. Seal, pp 110 - 117, Park Ridge, New Jersey.

Pradhan, N. M. B. (2001). Rhinoceros conservation in Nepal. Participatory Biodiversity Conservation. (eds. M. K. Balla, S. Rayamajhi and N. M. B. Pradhan), pp 40 - 46. Proceeding of Regional Network seminar, FONAREM, Kahmandu, Nepal.

Rojas, M. (1992). The species problem and conservation: What we are protecting? Conservation Biology, 6, 2, 170-178.

Shaffer, M. L. (1981) Minimum population size for species conservation. Bioscience. 31, $131-134$.

Shrestha, M. N. (1979). Internal migration of people in Nepal. Eastern Anthropologist, 32, 3, $163-176$.

Sinha, S. P. \& V. B. Sawarkar (1993) Management of the reintroduce great one horned rhinoceros (Rhinoceros unicornis) in Dudha National Park, Uttar Pradesh, India. In Rhinoceros Biology and Conservation. (ed.O. A. Ryder), pp. 218 - 337. Proceeding of an International Conference, Zool Society, San Diego, USA.

Smith, J. L. D., S. C. Ahearn, \& C. McDougal (1998) A landscape analysis of tiger distribution and habitat quality in Nepal. Conservation Biology. I, 12, 1388 - 1346.

Soule, M. E. (1987) Introduction. Viable population for conservation. (ed. M. E. Soule) Cambridge University Press, Cambridge.

Studsrød, J. E. \& P. Wegge (1995) Park people relatioship: The case of damage cause by park animals around Royal Bardia National Park, Nepal. Environmental Conservation, 22, 2,133 - 142.

ten Velde, P. F. (1999) Transboundary elephant corridors: Protecting the wild elephant dispersal pattern of the Far-Western Terai region through corridor linking. WWF Nepal Program, Nepal 
Vaugan, C (1991) Forest management and wildlife conservation in Central America: What are the options. Wildlife Conservation, Present trends and Perspectives for the 21st century (ed. Naoki Maruyama et al.) pp. 69-73. Proceeding of thelnternational symposium on Wildlife Conservation in Tsukuba and Yokohama, Japan

Wikramanayake, E. D, E. Dinerstein, J.C. Robinson, U. Karanth, A. Rabinowitz, D. Olson, T. Mathew, P. Hedado, M. Conner, G, Hemley \& D. Bolze (1998) An ecological based method for defining priorities for large mammal conservation: The tiger as case study. Conservation biology, 12, 4, 865-878.

William, N.L. (1993) Theory and pragmatism in the conservation of rhinos. pp 69-81. In

Rhinoceros Biology and Conservation (O.A.Ryder, ed.), Proceeding of an International Conference, Zool. Society, San Diego, USA.

WWF, (2000) WWF in Nepal: Three Decades of Partnership in Conservation (1967 - 2000). WWF Nepal Program, Kathmandu Nepal.

WWF (2001) Terai Duar savanna and Grassland (IMO701)

http://www.worldwildlife.org/wildworld/profiles/terrestrial/im/im0701_full.html

\section{$\mathscr{8}$}

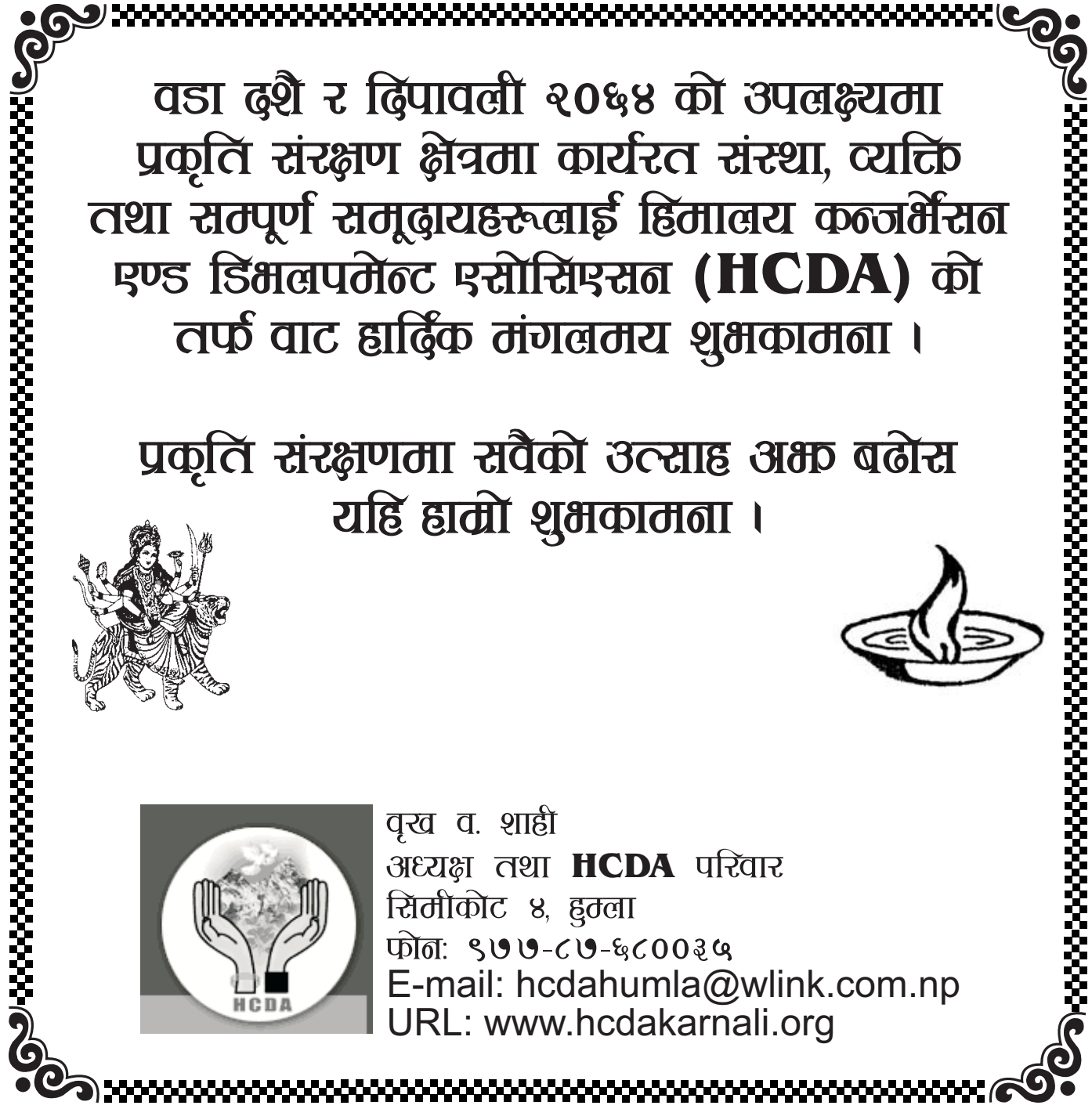

